\title{
The Missouri Groundwater-level Observation Well Network
}

The Missouri groundwater-level observation well network is a series of wells across the State of Missouri in which groundwater levels are monitored in real time and periodically. The wells monitor the water levels in multiple key aquifers, such as the Ozark aquifer in the Salem and Springfield Plateaus and the Mississippi Alluvial Plain aquifer in the South-eastern Lowlands. As of 2018, 150 real-time sites are operated as a cooperative effort between the Missouri Department of Natural Resources (MoDNR) and the U.S. Geological Survey (USGS; fig. 1). This fact sheet describes the network and well data from the network.

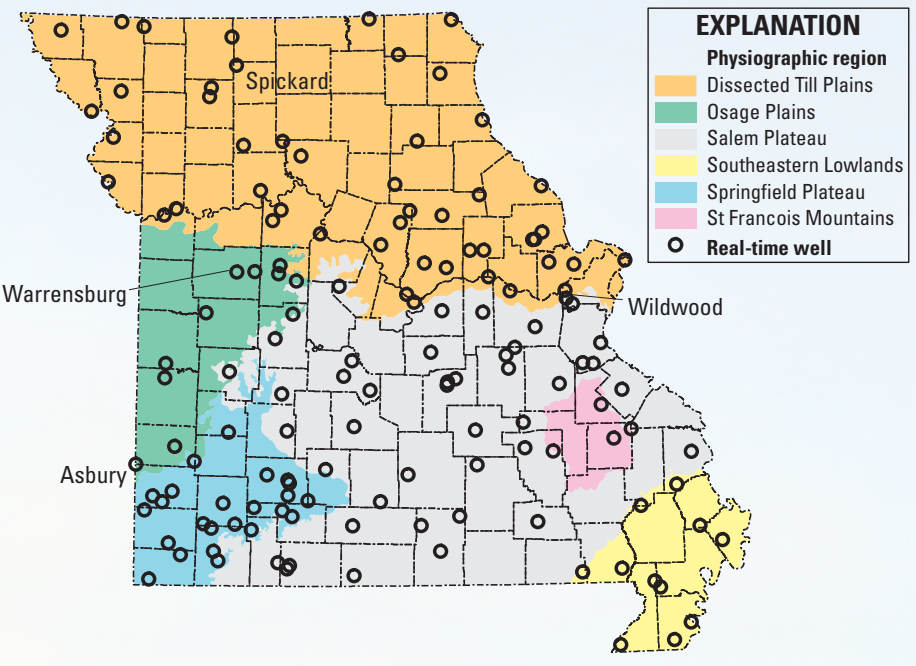

Figure 1. Missouri groundwater-level observation well network and physiographic regions. Modified from Miller and Vandike, 1997.

The MoDNR maintains the wells by regularly visiting each site. MoDNR personnel ensure that the equipment is operating properly and make manual water-level measurements to ensure that the data are accurate. MoDNR collects other well information, such as total depth, casing depth, stratigraphy, and lithology, and prepares figures that show water level in relation to aquifer thickness and well construction (fig. 2). Further information is available at https://dnr.mo.gov/geology/wrc/groundwater/ gwnetwork.htm.

Data are transmitted from the wells by satellite and are available from the USGS National Water Information System on the world wide web in near real time. The USGS processes these data, making corrections and ensuring that real-time measurements agree with the manual water-level measurements. The USGS makes occasional manual water-level measurements at key sites. Statistics are computed so that recent groundwater levels can be compared to historical levels to assess trends. For example, statistics such as daily and monthly mean water levels and 25th and 75th percentiles computed for the observation well near Spickard, Mo., completed in the glacial drift aquifer show that 2016-17 water levels are among the highest in the 45 years of record for this site (fig. 3).

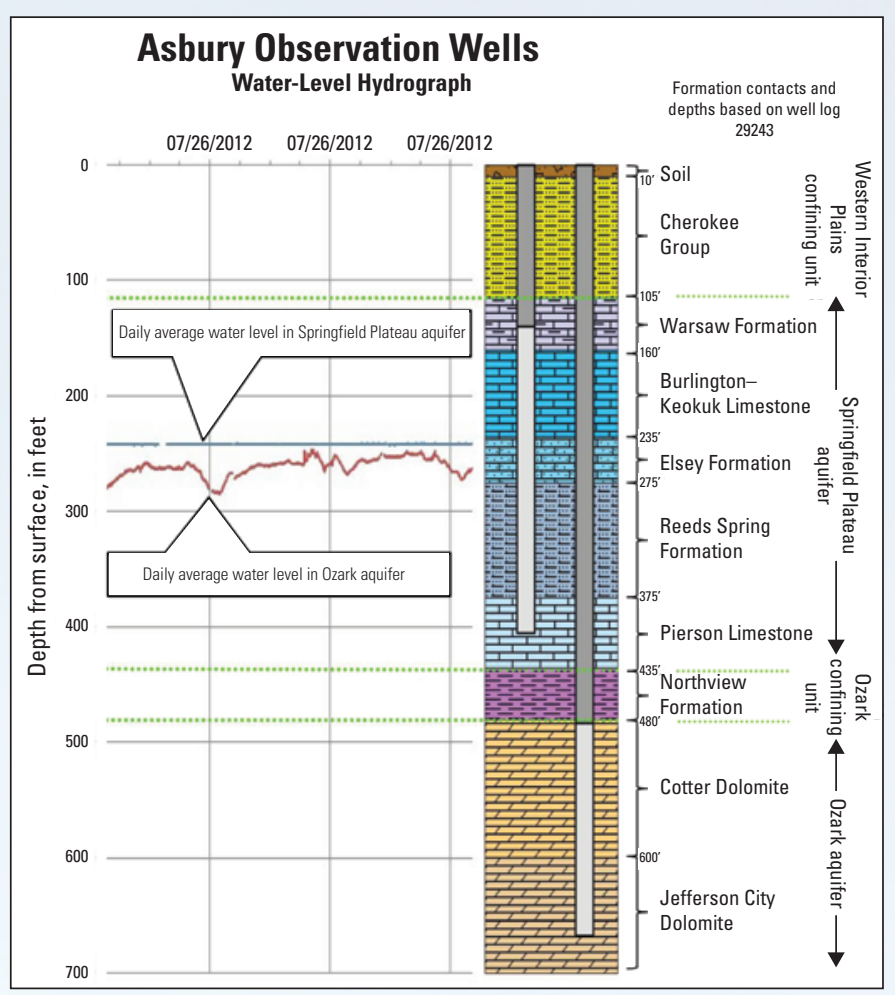

Figure 2. Stratigraphy, well construction, and water levels for the paired wells at Asbury, Mo. Modified from Missouri Department of Natural Resources, 2018 (https://dnr.mo.gov/geology/wrc/ groundwater/strathydrographs/asbury_combined.pdf). Dark gray section of the well indicates casing interval and light gray section of the well indicates open interval.

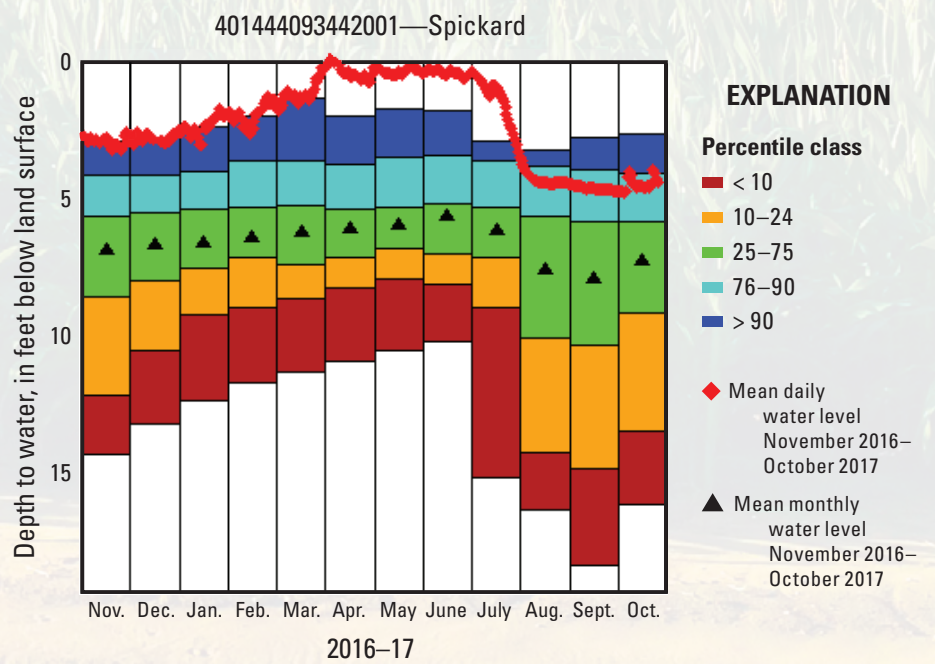

Figure 3. Depth to water, mean monthly water levels, and mean daily water levels exceeding the 75th percentile of historical water levels for Spickard well, Mo., November 2016-October 2017. 
Groundwater-level data have been recorded at some sites for more than 50 years. These long-term data are critical for understanding the aquifers in Missouri. Changes in groundwater levels can be affected by natural and human-induced factors. Natural factors include precipitation, changes in river stage, drought, earthquakes, barometric pressure changes, and tidal effects. Human-induced changes are generally related to the pumping of groundwater.

Parts of Missouri have an abundance of groundwater, whereas other areas lack a reliable groundwater source. Some wells in the network have had an overall decline (fig. 4) in water levels during the period of record, such as the well near Warrensburg, whereas some have had increases.

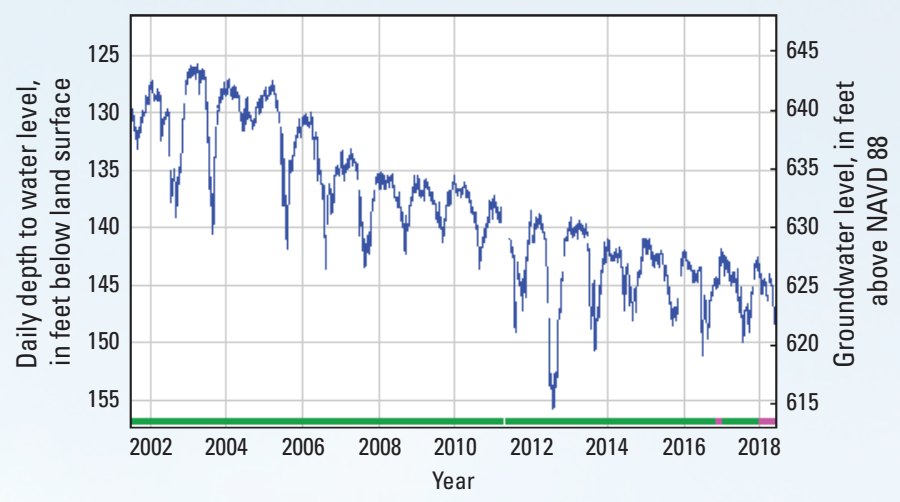

EXPLANATION

_ Daily mean depth to water level __ Period of approved data

_ Period of provisional data

Figure 4. Hydrograph showing groundwater-level decline at the Ozark aquifer well at Warrensburg, Mo.

Groundwater is one of Missouri's most valuable natural resources (Miller and Vandike, 1997). Many municipalities rely on groundwater as their primary source of water, and more than one-third of the approximately 797 million gallons per day (Mgal/d) withdrawn in 2015 for public supply in Missouri was from groundwater sources (Dieter and others, 2018). Groundwater is critical for tens of thousands of rural residents, and selfsupplied domestic groundwater withdrawal was approximately $57.5 \mathrm{Mgal} / \mathrm{d}$ in 2015. Groundwater is important for many other industries in the State, such as agriculture, mining, and power generation (Dieter and others, 2018).

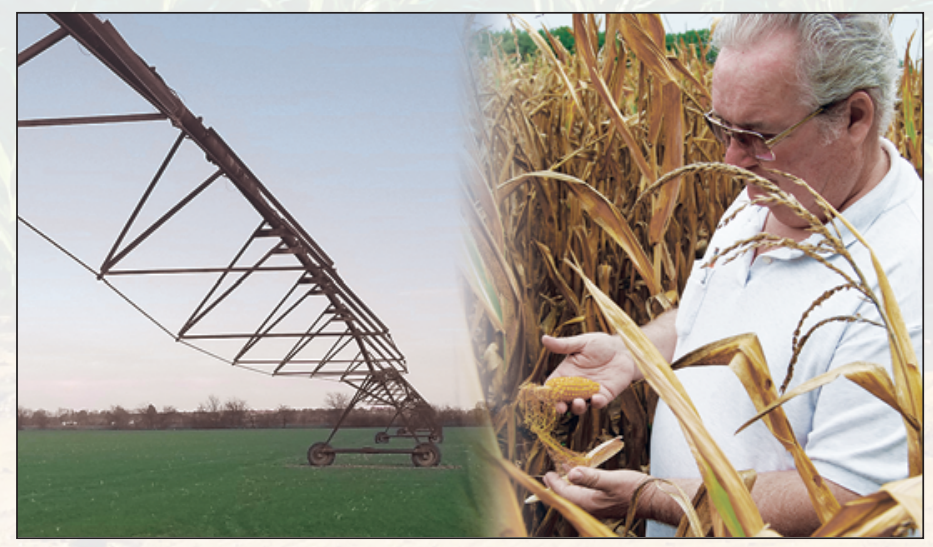

Agriculture, the largest industry in Missouri, depends on groundwater. During 2015, approximately $1,300 \mathrm{Mgal} / \mathrm{d}$ of groundwater was withdrawn for irrigation, and 16.1 Mgal/d was withdrawn for livestock (Dieter and others, 2018). Agriculture can be greatly affected by droughts (fig. 5), and the observation well network is valuable in assessing the effect and severity of droughts on groundwater supply. During the 2012 drought, many wells in the network, such as the Ozark aquifer well at Wildwood, had a decline in water levels (fig. 6).

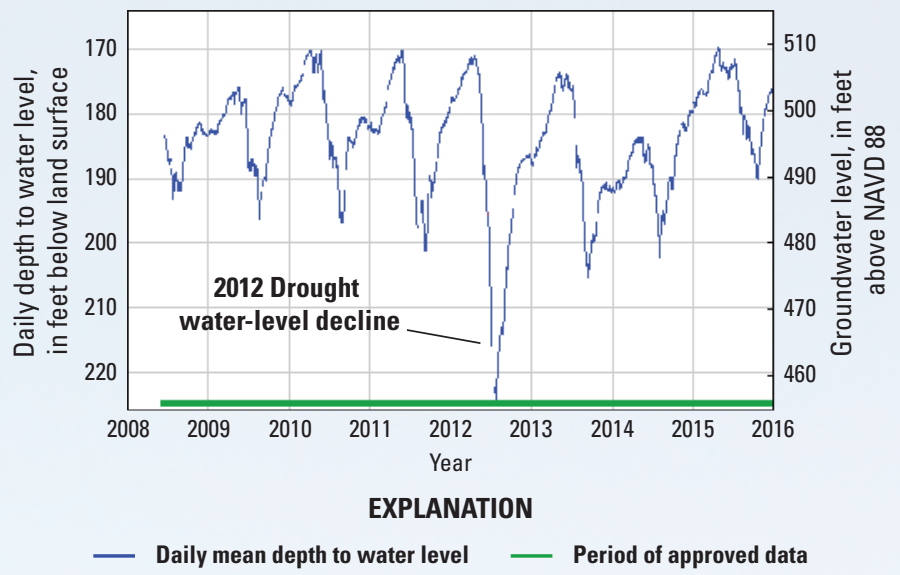

Figure 6. Hydrograph showing groundwater-level decline during the 2012 drought in the Ozark aquifer well at Wildwood, Mo.

\section{References Cited}

Dieter, C.A., Maupin, M.A., Caldwell, R.R., Harris, M.A., Ivahnenko, T.I, Lovelace, J.K., Barber, N.L., and Linsey, K.S., 2018, Estimated use of water in the United States in 2015: U.S. Geological Survey Circular 1441, 65 p. [Also available at https://doi.org/10.3133/cir1441.]

Miller, D.E., and Vandike, J.E., 1997, Groundwater resources of Missouri, in Missouri State Water Plan Series: Rolla, Mo., Geological Survey and Resource Assessment, Water Resources Report Number 46, v. II, 210 p. [Also available at https://dnr.mo.gov/pubs/WR46.pdf.]

Missouri Department of Natural Resources, 2018, Asbury Observation Wells: Rolla, Mo., $1 \mathrm{p}$.

\section{By David C. Smith}

For more information concerning this publication, contact:

Director, Central Midwest Water Science Center

U.S. Geological Survey

1400 Independence Road, MS-100

Rolla, MO 65401

(573) 308-3667

Or visit the Missouri Water Science Center Web site at: https://www.usgs.gov/centers/cm-water

Scott Kaden, R.G.

Groundwater Section Chief

Missouri Geological Survey-Water Resources Center

P.O. Box 250

Rolla, M0 65402

Phone: (573) 368-2194

Fax: (573) 368-2193

Or visit the Missouri Department of Natural Resources site at: https://dnr.mo.gov/
Figure 5. Pivot irrigation in the Missouri Bootheel in the southeastern part of the State (left). Farmer inspecting the effects of drought on crops (right), photograph by Kelly L. Warner, USGS.
ISSN 2327-6916 (print) ISSN 2327-6932 (online) https://doi.org/10.3133/fs20193009 